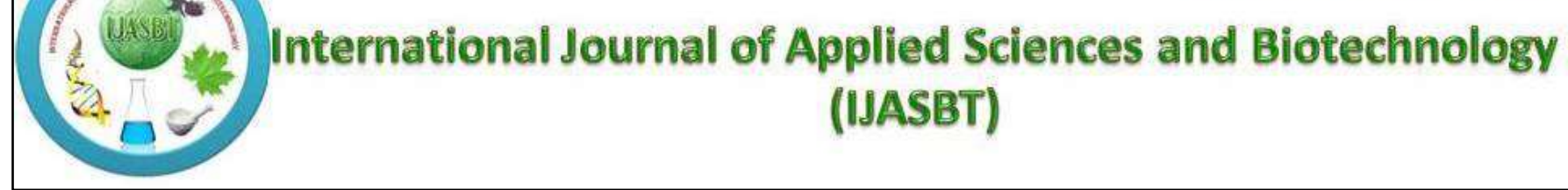

Research Article

\title{
COMPARATIVE STUDY ON PLANT GROWTH PROMOTION BY ENDOPHYTIC PSEUDOMONAS SPP. AND BACILLUS SPP. OF SOLANUM LYCOPERSICUM
}

\author{
Sampada Mishra ${ }^{1}$, Saroj Kumar Mahato ${ }^{1}$, Sabin Basi ${ }^{2 *}$ and Shradha Basi-Chipalu ${ }^{1}$ \\ ${ }^{1}$ SANN International College, Kathmandu, Nepal \\ ${ }^{2}$ International Maize and Wheat Improvement Center (CIMMYT), South Asia Regional Office, Kathmandu, Nepal \\ *corresponding author's email: sabinbasi@hotmail.com
}

\begin{abstract}
Minimization of deleterious effects of chemical fertilizers on health, ecosystem and economy can only be achieved by finding healthy, ecofriendly and cheap alternatives. Naturally selected symbiotic relationship between the endophytic bacteria and their host plants makes them an ideal candidate as biofertilizer. They can synthesize various plant growth hormones as well as assist their host in uptake of nutrients from soil.

The study was designed to compare plant growth promotion of Solanum lycopersicum by Bacillus spp., Pseudomonas spp. and total endophytic community isolated from roots of S. lycopersicum, grown in the soil samples collected from various locations of Kathmandu valley of Nepal. Tomato seeds were inoculated with mixtures of eight endophytic strains of Bacillus spp. and Pseudomonas spp., and crude endophytes obtained from each location separately.

Endophytic treatments, except Pseudomonas spp., inhibited seminal root growth during 12-days germination period. However, after plantation, root and shoot biomass was enhanced by the endophytes, with no significant differences among the bacterial treatments. The shoot height was also enhanced, among which Pseudomonas spp. had the strongest effect. In phosphate solubilization assay, out of seventy-two isolates each of Bacillus spp. and Pseudomonas spp. tested, twenty-four isolates of Pseudomonas spp. and sixteen isolates of Bacillus spp. could solubilize phosphate. Higher number of phosphate solubilizing isolates of Pseudomonas spp. might provide a possible explanation for the greater enhancement of shoot height by Pseudomonas spp. as compared to Bacillus spp.
\end{abstract}

Keywords: Endophyte; Bacillus; Pseudomonas; Tomato; Plant Growth Promotion

\section{Introduction}

Consumption of chemical fertilizers is increasing to keep up with the demands of growing world population. The average application of chemical fertilizers in Nepal was 31 $\mathrm{kg} /$ hectare in 1995 , which is expected to reach up to 131 $\mathrm{kg} /$ hectare by 2017 (Shrestha, 2010). However, the excessive use of chemical fertilizers can result in various environmental problems, such as of deterioration of water quality, harming of beneficial organisms (Hautier et al., 2009), increased emission of greenhouse gases, and in a large scale may also contribute to climate change (Crutzen et al., 2007).

Chemical fertilizers such as Ammonium sulphate and Urea are found to cause acidification of the soil (Chitrakar, 1990). As the $\mathrm{pH}$ of the soil decreases, the amount of soluble Phosphorous, which has maximum solubility in the $\mathrm{pH}$ range of 6.2-7.0, also decreases. It may be daunting to use Phosphate fertilizers to cope with this problem. However, phosphate fertilizers cannot be the ultimate solution since the soluble phosphates are rapidly immobilized to insoluble forms with aluminum and iron ( Sharma et al., 2013) which results in the loss of $70 \%$ of the soluble phosphates from the phosphate fertilizers. Other $10 \%$ is lost to run-off and leaching (Sashidhar and Podile, 2010). Hence, only 10-20\% of the soluble phosphates added is available for the utilization by plants. On the other hand, phosphorus for the production of phosphate fertilizers is derived from phosphorite, a non-renewable resource which has been estimated to deplete severely within the next 50-100 years (Cordell, 2010). Therefore, it is necessary to find alternative solutions to address the need of soluble phosphorus in agriculture.

Endophytic bacteria can be an environment friendly, sustainable alternative to chemical fertilizers. These bacteria reside inside plant tissues (Hallmann et al., 1997) where they benefit the host plant by making nutrients 
available to the plant, production of plant growth hormones and control of phytopathogens (Bloemberg and Lugtenberg, 2001). They are also termed as plant growth promoting bacterial endophytes (PGPBEs) (Hardoim et al., 2008); and are free living rhizospheric bacteria, able to infect the plant through active penetration under favorable conditions. Endophytes are environment friendly and also economical. Compared to large industries required to manufacture chemical fertilizers, microbial fertilizers such as endophytic bacteria can be cultured with the help of small budget and resources. Likewise, as endophytes are component of nature, they are less likely to degrade the soil quality and soil microbiome. Hence it is necessary to develop microbial fertilizers to replace chemical fertilizers in order to ensure healthy growth in crop yields.

Despite of all these advantages, very few works have been conducted regarding the isolation of endophytes in Nepal. National Agricultural Research Council (NARC) soil division has one of the few laboratories in Nepal, actively isolating local and imported strains of Rhizobium and providing them to farmer as biofertilizer packets for legumes (National Agricultural Research Council, 2015). However, research regarding other strains of endophytic bacteria must also be done in order to use them as fertilizers on crops other than legumes. Hence this study was designed to isolate the root endophytes of Solanum lycopersicum (tomato) grown in different soil samples from Kathmandu valley and assess their role in growth promotion of tomato plants.

\section{Materials and Methods}

\section{Sample Preparation}

Soil samples were collected from three different locations each of Kathmandu (Thankot, Balaju and Muhan Pokhari), Lalitpur (Lele, Godawari and Bagdol) and Bhaktapur districts (Bodey, Kamal Binayak and Surya Binayak). Tomato seeds of Srijana variety (hybrid) from Gorkha Seeds Co. Pvt. Ltd were germinated on moist filter papers in Petri plates and incubated at $30{ }^{\circ} \mathrm{C}$ in dark for 3 days, followed by incubation in $14 \mathrm{hr}$ light/10 hr dark photoperiod conditions. Germinated seedlings were then transferred to plastic pots (Changshu Yangyuan Chemical China) containing approximately $1000 \mathrm{~cm}^{3}$ soil sample and grown in screen house.

\section{Isolation of Bacterial Endophytes}

Bacterial endophytes were isolated from the roots of 7 weeks old tomato plants. Roots were surface disinfected by emerging in $70 \%$ ethanol for 30 seconds and then $2 \%$ sodium hypochlorite for 5 minutes, followed by three rinses in sterilized distilled water, and then mashed in $1000 \mu \mathrm{L}$ of sterile saline to prepare crude root extract (Long et al., 2003). To isolate Bacillus spp., the crude root extract was subjected to heat shock at a constant temperature on water bath at $80{ }^{\circ} \mathrm{C}$ for $15 \mathrm{~min}$ (Marquis and Bender, 1985) and then spread on Nutrient Agar. The isolation of Pseudomonas spp. was done using King's B medium and Pseudomonas Selective Agar Base (HiMedia Laboratories) supplemented with CFC (Cetrimide, Fucidin, Cephaloridine). Disinfection was verified by plating aliquots of the sterile distilled water used in the final rinse on Nutrient Agar plates and incubating the plates at $37{ }^{\circ} \mathrm{C}$ for 48 hours (Mendes et al., 2007). Eight different colonies of Bacillus spp. and Pseudomonas spp. were isolated from each of the nine samples.

\section{Phosphate Solubilization}

The ability of isolated Pseudomonas spp. and Bacillus spp. to solubilize phosphate was studied using Pikovskaya agar (HiMedia Laboratories) plates. Isolates were spotted onto Pikovskaya agar and incubated for 10 days at $37{ }^{\circ} \mathrm{C}$. The presence of a clear halo zone around the bacterial colony due to the utilization of tricalcium phosphate present in the medium was considered as an indicator for positive test of phosphate solubilization.

\section{Evaluation of Effect of Endophytes on Plant Growth Promotion}

Surface sterilized seeds of tomato (Srijana hybrid) were separately soaked in three different treatments of bacterial broth cultures (O.D. 0.24 A) viz., crude root extract, mixture of eight colonies of Bacillus spp. and mixture of eight colonies of Pseudomonas spp. isolated from each of the nine samples. Seeds soaked in nutrient broth were used as control. Following germination of the seeds (12 days), germination percentage and seminal root length were measured, and the three seedlings were grown in each pots containing sterile soil $\left(\sim 1000 \mathrm{~cm}^{3}\right)$ inside the screen house for the next 4 weeks. Three replications were done for each treatment and the pots were arranged in a randomized complete block design (RCBD) with the help of $\mathrm{R}$ programming (R Development Core Team, 2008). Shoot length of seedlings were measured each week after planting to assess any difference in the plant growth. After 4 weeks, one plant from each of the pots was uprooted and the biomass of the shoot and the root were taken using a weighing machine (OHAUS - PRECISION Standard).

\section{Statistical Analysis and Data Presentation}

Data were statistically analyzed using IBM SPSS (version 23). Data satisfying for normality test (KolmogorovSmirnov) and homogeneity of variance (leven's test), were subjected to One-way ANOVA at $\mathrm{P}<0.05$ level of significance, and the means were separated using the DMRT test at $\mathrm{P}<0.05$. Graphs were prepared in Microsoft Office Excel@.

\section{Results and Discussions}

The effect of endophytic bacteria on seed germination was assessed. In this assessment, seed germination remained unaffected by the endophytic treatments (Fig. 1). However, the seminal root lengths of the germinating seeds were 
inhibited by the crude endophytic bacteria and the Bacillus spp. (Fig. 2). The seminal root lengths of the germinating seeds treated with Pseudomonas spp. however was not significantly different from that of control. Non-significant difference in germination percentage between the bacterial treatments and control might be attributed to insufficient release of gibberellic acid by bacteria to impart any significant difference in seed germination. Likewise, it is also possible that the endophytes could not enter the seeds until its germination. And, only after seeds germinated, endophytes were able to reach the tissues through their seminal roots and could affect the root growth. The inhibition of seminal root growth by the Bacillus spp. treatments can be imputed to auxin induced synthesis of ethylene which inhibits root elongation at high concentrations. Indole acetic acid synthesized by bacteria may be involved in the rise of ethylene level to an excessive concentration as demonstrated by (Romano et al., 1993). IAA at a concentration greater than $1 \mathrm{uM}$, can stimulate the activity of the enzyme ACC synthase, which is responsible for the production of ethylene (Lieberman, 1979). Various experiments have shown endophytic Bacillus spp. to produce greater concentrations of auxin (Araújo et al., 2005; Murugappan et al., 2013; Talboys et al., 2014).

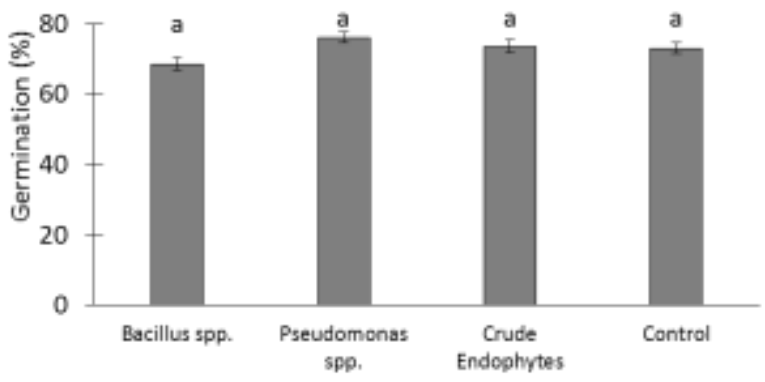

Fig. 1: Effect of bacterial treatments on the germination percentage of tomato seeds. Germination percentage of untreated seeds represent control. Similar letter above Mean \pm S.E. (harmonic mean sample size, $n=9$ ) represent non-significant difference at $\mathrm{P} \leq 0.05$, DMRT

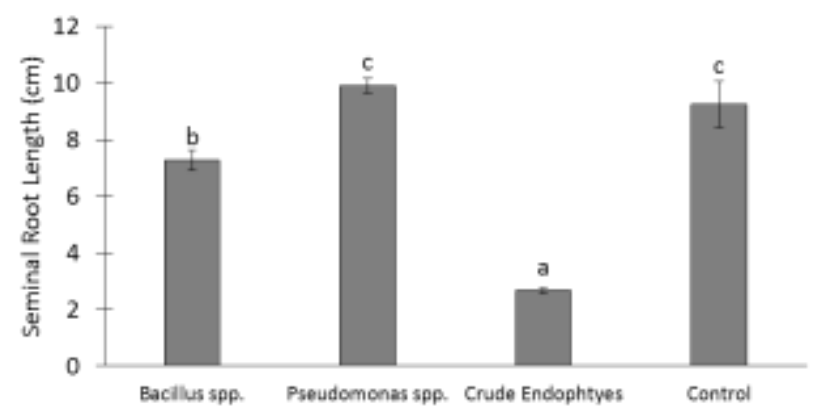

Fig. 2: Effect of bacterial treatments on the root length of seedlings. Root length of untreated seedlings represent control. Similar letter above Mean \pm S.E. (harmonic mean sample size, $\mathrm{n}=30$ ) represent nonsignificant difference at $\mathrm{P} \leq 0.05$, DMRT
The treatments of the seeds with endophytic Pseudomonas spp. showed significant enhancement of the production of root biomass compared to the control (Fig. 3). However, the dry weight of the plants developed from the seeds treated with Pseudomonas spp. was not significantly greater than those treated with Bacillus spp. or crude endophytes. The shoot biomass production was significantly enhanced by the endophytic treatments compared to the control (Fig. 4). However, there was no significant difference among the bacterial variation. Shoot height growth was significantly enhanced by endophytic treatments compared to the control. Among the endophytes, Pseudomonas spp. exhibited greatest effect on the growth of shoot height (Fig. 5 ). This result was consistent throughout the four weeks of observation (Fig. 6).

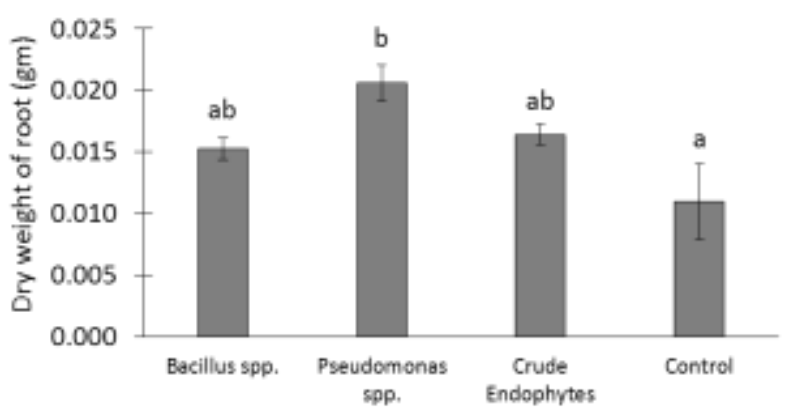

Fig. 3: Effect of bacterial treatments on the dry weight of roots. Dry weight of roots of the untreated plants represent control. Similar letter above Mean \pm S.E. (harmonic mean sample size, $n=9$ ) represent nonsignificant difference at $\mathrm{P} \leq 0.05$, DMRT.

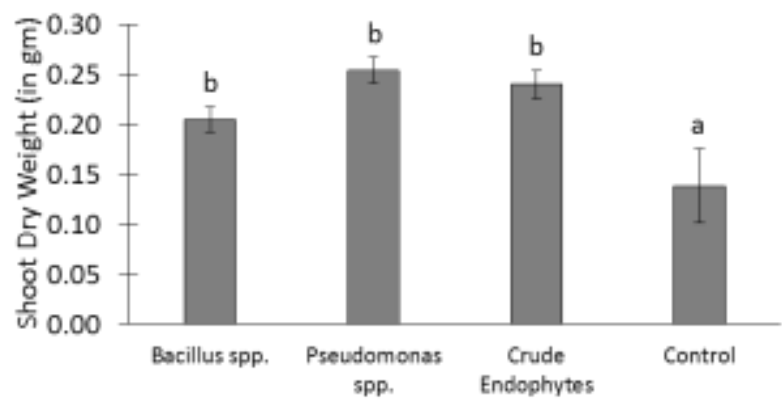

Fig. 4: Effect of bacterial treatments on the dry weight of shoots. Dry weight of shoots of untreated plants represent control. Similar letter above Mean \pm S.E. (harmonic mean sample size, $n=9$ ) represent nonsignificant difference at $\mathrm{P} \leq 0.05, \mathrm{DMRT}$.

The observed promotion of shoot and root biomass production in the plants compared to that of the control can be related to various services of the endophytic bacteria to the plants that they inhabit. For host plants, endophytes can enhance plant nutrient uptake, enhance tolerance to abiotic stresses, inhibit infection by plant pathogens, and produce growth regulators, which consequently, increase biomass yield of the plants (Compant et al., 2005; Hardoim et al., 2008; Muthukumarasamy et al., 2002). 


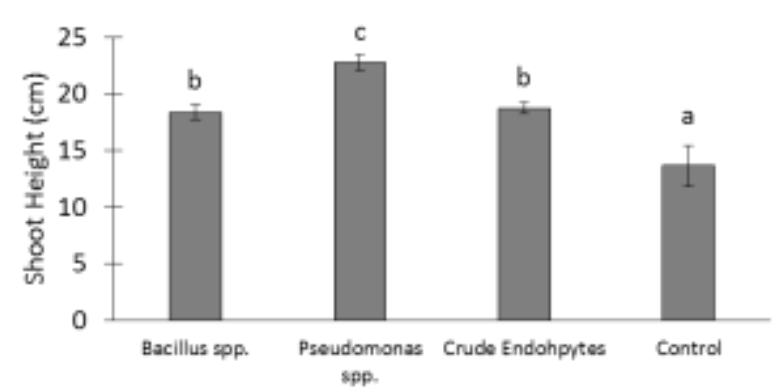

Fig. 5: Effect of bacterial treatments on the shoot height after 4 weeks. Shoot height of untreated plants represent control. Similar letter above Mean \pm S.E. (harmonic mean sample size, $\mathrm{n}=19.2$ ) represent nonsignificant difference at $\mathrm{P} \leq 0.05$, DMRT.

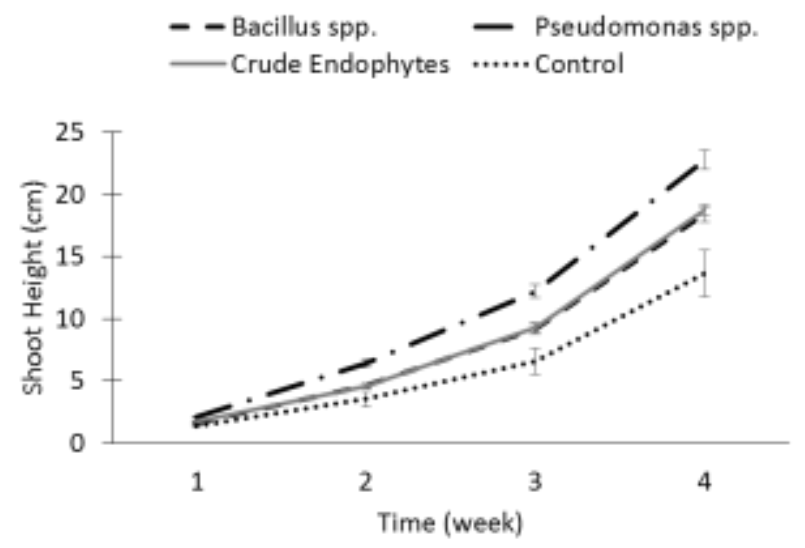

Fig. 6: The growth trend of the seedlings over 4 weeks as effects of various endophytic treatments as compared to control. Shoot height of untreated plant represent the control. Error bars represent the standard error of means.

It is important to note that the seminal root growth was inhibited during seed germination; however, the root biomass during the active plant growth phase in the soil was promoted. Ethylene, as proposed, might have inhibited the root elongation during the germination phase (without added nutrient); but during the active plant growth phase in the soil, plants had access to the nutrients in the soil. Endophytic bacteria might also have enhanced the nutrient uptake by various mechanisms to convert the nutrients into plant-utilizable forms, counteracting the inhibiting effect on root growth.

Endophytic treatments showed significantly better growth of shoot heights compared to the control. One of the various reasons for such result could be the bacterial production of cytokinin - one of the few plant growth promoters, that promote cell division (D’Agostino and Kieber, 1999). Both Bacillus spp. and Pseudomonas spp. have been found to synthesize cytokinins (Hussain and Hasnain, 2009). The other reason could be the production of auxins by endophytes (Patel and Patel, 2014) which might have resulted in significantly better growth of plants compared to that of the control. In addition to such hormonal regulation, endophytic bacteria is also found to have phosphate solubilizing activities.

Among, seventy-two isolates each of Bacillus spp. and Pseudomonas spp., sixteen isolates of Bacillus spp. and twenty-four isolates of Pseudomonas spp. showed positive tests for mineral phosphate solubilization. This higher number of phosphate solubilizing isolates of Pseudomonas spp. as compared to that of Bacillus spp., provide a possible link to having stronger shoot height promotion by Pseudomonas spp. The other possible reason could be the activity of ACC deaminase. Inoculation of maize with the PGPR containing ACC-deaminase, resulted in a significant increase in the root growth, shoot length and shoot weight of plants (Arshad et al., 2008). Akhgar et al., (2014), found that fluorescent Pseudomonas group of Canola (Brassica napus), were able to utilize ACC as a sole source of nitrogen. Also, all the strains possessing ACC deaminase tested positive for IAA production. Likewise, Glick, (2005), identified that the deleterious effects of high levels of ethylene, produced due to overproduction of IAA, is reduced by ACC deaminase.

Likewise, non-significant difference between the shoot height promotions due to crude endophytes as compared to that due to Bacillus spp., might be ascribed to the production of bacteriocins by Bacillus spp. Endophytic Bacillus spp. have been found to produce bacteriocins as biocontrol compounds (Araújo et al., 2005; Ashwini and Srividya, 2013; Gray et al., 2006; I. Hammami et al., 2009; Ines Hammami et al., 2012; He et al., 2006; Hu et al., 2010; Lee et al., 2009; Mouloud et al., 2013). Hence, when, the crude endophytes were used to inoculate the seeds, Bacillus spp. might have dominated the endophytic population and therefore, the plant growth promotion shown by crude endophytes were similar to that shown by Bacillus spp.

\section{Conclusion}

Endophytic bacteria promote plant growth through mechanisms such as phosphate solubilization, phytohormones production and lowering of plant ethylene levels. Endophytes had no effect in germination of tomato seeds, but increased root and shoot biomass, and the shoot length. Among the endophytic treatments, Pseudomonas spp. as compared to Bacillus spp. or the crude endophytes were more effective in tomato shoot height promotion. Hence, the use of Pseudomonas spp. provides promises as an alternative to chemical fertilizer for sustainable tomato cultivation. However, further investigations are needed to assess the efficiency of the endophytes as biofertilizer in field conditions.

\section{Acknowledgement}

We would like to thank the Department of Biotechnology at SANN International College, Kathmandu for the funds and laboratory facilities that were required for the completion of the research. 


\section{References}

Akhgar AR, Arzanlou M, Bakker PAHM and Hamidpour M (2014). Characterization of 1-Aminocyclopropane-1Carboxylate (ACC) deaminase-containing Pseudomonas spp. in the Rhizosphere of salt-stressed canola. Pedosphere 24: 461-468. DOI: 10.1016/S1002-0160(14)60032-1

Araújo FF, Henning AA and Hungria M (2005). Phytohormones and antibiotics produced by Bacillus subtilis and their effects on seed pathogenic fungi and on soybean root development. World Journal of Microbiology and Biotechnology 21: 1639-1645. DOI: 10.1007/s11274005-3621-x

Arshad M, Shaharoona B and Mahmood T (2008). Inoculation with Pseudomonas spp. Containing ACC-Deaminase Partially Eliminates the Effects of Drought Stress on Growth, Yield, and Ripening of Pea (Pisum sativum L.). Pedosphere 18: 611-620. DOI: 10.1016/S10020160(08)60055-7

Ashwini N and Srividya S (2013). Potentiality of Bacillus subtilis as biocontrol agent for management of anthracnose disease of chilli caused by Colletotrichum gloeosporioides OGC1. 3 Biotech 4: 127-136. DOI: 10.1007/s13205-013-0134-4

Bloemberg GV and Lugtenberg BJJ (2001). Molecular basis of plant growth promotion and biocontrol by rhizobacteria. Current Opinion in Plant Biology. 4: 343-350 DOI: 10.1016/S1369-5266(00)00183-7

Chitrakar PL (1990). Planning, agriculture, and farmers: strategy for Nepal. Retrieved from http://agris.fao.org/agrissearch/search.do?recordID=XF2015014886\#.VzxKkCaU WQU.mendeley

Compant S, Reiter B, Nowak J, Sessitsch A, Clément C and Barka EA (2005). Endophytic Colonization of Vitis vinifera L. by Plant Growth- Promoting Bacterium Burkholderia sp. Strain PsJN. Applied and Environmental Microbiology 71: 1685-1693. DOI: 10.1128/AEM.71.4.1685

Cordell D (2010). The Story of Phosphorus: Sustainability implications of global phosphorus scarcity for food security.

Crutzen PJ, Mosier AR, Smith KA and Winiwarter W (2007). N2O release from agro-biofuel production negates global warming reduction by replacing fossil fuels. Atmospheric Chemistry and Physics Discussions 7: 11191-11205. DOI: 10.5194/acpd-7-11191-2007

D'Agostino IB and Kieber JJ (1999). Molecular mechanisms of cytokinin action. Current Opinion in Plant Biology 2: 359364 DOI: 10.1016/S1369-5266(99)00005-9

Glick BR (2005). Modulation of plant ethylene levels by the bacterial enzyme ACC deaminase. FEMS Microbiology Letters 251: 1-7. DOI: 10.1016/j.femsle.2005.07.030

Gray EJ, Lee KD, Souleimanov AM, Di Falco MR, Zhou X, Ly A, Charles TC, Driscoll BT and Smith DL (2006). A novel bacteriocin, thuricin 17 , produced by plant growth promoting rhizobacteria strain Bacillus thuringiensis NEB17: Isolation and classification. Journal of Applied
Microbiology 100: 545-554. DOI: 10.1111/j.13652672.2006.02822.x

Hallmann J, Quadt-Hallmann A, Mahaffee WF and Kloepper JW (1997). Bacterial endophytes in agricultural crops. Canadian Journal of Microbiology 43: 895-914. DOI: $10.1139 / \mathrm{m} 97-131$

Hammami I, Jaouadi B, Bacha AB, Rebai A, Bejar S, Nesme X and Rhouma A (2012). Bacillus subtilis bacteriocin Bac 14B with a broad inhibitory spectrum: Purification, amino acid sequence analysis, and physicochemical characterization. Biotechnology and Bioprocess Engineering 17: 41-49. DOI: 10.1007/s12257-010-04018

Hammami I, Rhouma A, Jaouadi B, Rebai A and Nesme X (2009). Optimization and biochemical characterization of a bacteriocin from a newly isolated Bacillus subtilis strain 14B for biocontrol of Agrobacterium spp. strains. Letters in Applied Microbiology 48: 253-260. DOI: 10.1111/j.1472-765X.2008.02524.X

Hardoim PR, van Overbeek LS and van Elsas JD (2008). Properties of bacterial endophytes and their proposed role in plant growth. Trends in Microbiology 16: 463-471. DOI: $10.1016 /$ j.tim.2008.07.008

Hautier Y, Niklaus PA and Hector A (2009). Competition for light causes plant biodiversity loss after eutrophication. Science (New York, N.Y.) 324: 636-638. DOI: 10.1126/science. 1169640

He L, Chen WL and Liu Y (2006). Production and partial characterization of bacteriocin-like pepitdes by Bacillus licheniformis ZJU12. Microbiological Research 161: 321326. DOI: 10.1016/j.micres.2005.12.002

$\mathrm{Hu} \mathrm{HQ}, \mathrm{Li} \mathrm{XS}$ and $\mathrm{He} \mathrm{H} \mathrm{(2010).} \mathrm{Characterization} \mathrm{of} \mathrm{an}$ antimicrobial material from a newly isolated Bacillus amyloliquefaciens from mangrove for biocontrol of Capsicum bacterial wilt. Biological Control 54: 359-365. DOI: 10.1016/j.biocontrol.2010.06.015

Hussain A and Hasnain S (2009). Cytokinin production by some bacteria: Its impact on cell division in cucumber cotyledons. African Journal of Microbiology Research 3: 704-712.

Lee KD, Gray EJ, Mabood F, Jung WJ, Charles T, Clark SR, Ly A, Souleimanov A, Zhou X and Smith DL (2009). The class IId bacteriocin thuricin-17 increases plant growth. Planta 229: 747-755. DOI: 10.1007/s00425-008-0870-6

Lieberman M (1979). Biosynthesis and Action of Ethylene. Annual Review of Plant Physiology 30:, 533-591. DOI: 10.1146/annurev.pp.30.060179.002533

Long HH, Furuya N, Kurose D, Takeshita M and Takanami Y (2003). Isolation of endophytic bacteria from Solanum sp. and their antibacterial activity against plant pathogenic bacteria. Journal of the Faculty of Agriculture, Kyushu University 48: 21-28.

Marquis RE and Bender GR (1985). Mineralization and Heat Resistance of Bacterial Spores. Journal of Bacteriology 161: 789-791. 
Mendes R, Pizzirani-Kleiner AA, Araujo WL and Raaijmakers JM (2007). Diversity of cultivated endophytic bacteria from sugarcane: genetic and biochemical characterization of Burkholderia cepacia complex isolates. Appl Environ Microbiol 73: 7259-7267. DOI: 10.1128/AEM.01222-07

Mouloud G, Daoud H, Bassem J, Atef IL and Hani B (2013). New bacteriocin from Bacillus clausii StrainGM17: Purification, characterization, and biological activity. Applied Biochemistry and Biotechnology 171: 21862200. DOI: 10.1007/s12010-013-0489-3

Murugappan R, Begum SB and Roobia RR (2013). Symbiotic influence of endophytic Bacillus pumilus on growth promotion and probiotic potential of the medicinal plant Ocimum sanctum. Symbiosis 60: 91-99. DOI: 10.1007/s13199-013-0244-0

Muthukumarasamy R, Revathi G and Loganathan P (2002). Effect of inorganic $\mathrm{N}$ on the population, in vitro colonization and morphology of Acetobacter diazotrophicus (syn. Gluconacetobacter diazotrophicus). Plant and Soil 243: 91-102. DOI: 10.1023/A:1019963928947

National Agricultural Research Council. (2015). A Handbook of Soil Science. NARC Soil Science Divisiom.

Patel MV and Patel RK (2014). Indole-3-Acetic Acid ( Iaa ) Production By Endophytic Bacteria Isolated From Saline Dessert, the Little Runn of Kutch. CIBTech Journal of Microbiology 3: 17-28.
R Development Core Team. (2008). R: A Language and Environment for Statistical Computing. Vienna, Austria. Retrieved from http://www.r-project.org

Romano CP, Cooper ML and Klee HJ (1993). Uncoupling Auxin and Ethylene Effects in Transgenic Tobacco and Arabidopsis Plants. The Plant Cell 5: 181-189. DOI: 10.1105/tpc.5.2.181

Sashidhar B and Podile AR (2010). Mineral phosphate solubilization by rhizosphere bacteria and scope for manipulation of the direct oxidation pathway involving glucose dehydrogenase 109: 1-12. DOI: $10.1111 /$ j.13652672.2009.04654.x

Sharma SB, Sayyed RZ, Trivedi MH and Gobi TA (2013). Phosphate solubilizing microbes : sustainable approach for managing phosphorus deficiency in agricultural soils, SpringerPlus 2: 587.

Shrestha RK (2010). Fertilizer Policy Development in Nepal, 126137.

Stenlid G (1982). Cytokinins as inhibitors of root growth. Physiologia Plantarum 56: 500-506. DOI: 10.1111/j.1399-3054.1982.tb04546.x

Talboys PJ, Owen DW, Healey JR, Withers PJ and Jones DL (2014). Auxin secretion by Bacillus amyloliquefaciens FZB42 both stimulates root exudation and limits phosphorus uptake in Triticum aestivium. BMC Plant Biol 14: 51. DOI: 10.1186/1471-2229-14-51 